\title{
Rancang Bangun Mesin Produksi Biodiesel Sistem Kontinyu Kapasitas 400 Liter/Jam
}

\author{
Suryanto $^{*}$, Sukma Abadi², Barka Amanah ${ }^{3}$ dan Wahyudin ${ }^{4}$ \\ 1,2,3,4 Jurusan Teknik Mesin, Politeknik Negeri Ujung Pandang, Makassar 90245, Indonesia \\ *suryanto@poliupg.ac.id
}

\begin{abstract}
Biodiesel is one type of biofuels (liquid fuels from processing vegetable oils or animal fats). The use of biodiesel in Indonesia in the last decade continues to increase biodiesel production so that the system continues to be developed in order to produce a continuous, high quality and efficient. Under these conditions, this research is done to increase the production of biodiesel by designing machines continuous system production capacity of 400 liters/hour using a series of control systems Arduino Mega 2560 on the means of production so as to obtain a continuous system with automatic control. The trial results biodiesel production engine of this study showed a capacity of 117 liters/hour/tank. From the results obtained products consisting of 12.5 liters of glycerol while the 104.5 liters of biodiesel. There are four tanks that work in sequence in order to obtain a total capacity of 420 liters/hour. The quality of the test results that have been tested biodiesel lab showed results in accordance with ISO standards.
\end{abstract}

Keywords: Biodiesel; Continuous System; Microcontroller

\begin{abstract}
Abstrak: Biodiesel merupakan salah satu jenis biofuel (bahan bakar cair dari pengolahan minyak nabati atau lemak hewani). Penggunaan biodiesel di Indonesia dalam dekade terakhir ini terus mengalami peningkatan sehingga sistem produksi biodiesel terus dikembangkan guna menghasilkan produk yang kontinyu, berkualitas dan efisien. Berdasarkan kondisi tersebut maka penelitian ini dilakukan untuk meningkatkan produksi biodiesel dengan merancang mesin produksi sistem kontinyu kapasitas 400 liter/jam menggunakan sistem kontrol seri Arduino Mega 2560 pada alat produksi sehingga diperoleh suatu sistem yang kontinyu dengan mengontrol secara otomatis. Hasil uji coba mesin produksi biodiesel dari penelitian ini diperoleh hasil kapasitas 117 liter/jam/tangki. Dari hasil tersebut diperoleh produk yang terdiri dari 12,5 liter gliserol sedangkan biodiesel 104,5 liter. Ada empat tangki yang bekerja secara sekuen sehingga diperoleh total kapasitas 420 liter/jam. Adapun dari hasil uji mutu biodisel yang telah diuji lab menunjukkan hasil yang sesuai dengan standar SNI.
\end{abstract}

Kata kunci : Biodiesel; Sistem Kontinyu; Microcontroller

\section{PENDAHULUAN}

Indonesia memiliki berbagai macam sumber daya alam yang dapat dijadikan sumber energi. Salah satunya adalah minyak bumi yang termasuk ke dalam sumber energi tidak terbarukan. Salah satu hasil pengolahan minyak bumi yang dijadikan sumber energi adalah bahan bakar minyak. Indonesia memiliki jumlah minyak bumi yang terbatas. Dengan semakin banyaknya penggunaan energi, maka berpotensi menimbulkan krisis energi. Terkait hal tersebut, penelitian mengenai energi alternatif terbarukan semakin banyak dilakukan. Salah satunya adalah pengembangan dan pemanfaatan biodiesel sebagai pengganti dari bahan bakar solar. Pertumbuhan ekonomi yang signifikan pada beberapa tahun terakhir menyebabkan konsumsi bahan bakar juga semakin meningkat. Jika kondisi ini kurang diantisipasi dengan usaha yang maksimal untuk mencari alternatif lain pada penyediaan energi yang berkesinambungan, maka hal tersebut berdampak buruk terhadap perkembangan ekonomi pada masa mendatang. Nama biodiesel telah disetujui oleh Department of Energi (DOE), Environmental Protection Agency (EPA) dan American Society of Testing Material (ASTM), biodiesel merupakan bahan bakar alternatif yang menjanjikan yang dapat diperoleh dari minyak tumbuhan, lemak binatang atau minyak bekas melalui esterifikasi dengan alkohol [1-3]. Biodiesel dapat digunakan tanpa modifikasi ulang mesin diesel. Biodiesel juga dapat ditulis dengan B100, yang menunjukkan bahwa biodiesel tersebut murni $100 \%$ monoalkil ester. Biodiesel campuran ditandai 
dengan "BXX", yang mana "XX" menyatakan persentase komposisi biodiesel yang terdapat dalam campuran. B20 berarti terdapat biodiesel $20 \%$ dan minyak solar $80 \%$ [4]. Karena bahan bakunya berasal dari minyak tumbuhan atau lemak hewan, biodiesel digolongkan sebagai bahan bakar yang dapat diperbarui [5].

Sebagai bahan bakar, biodiesel harus memenuhi persyaratan yang ditetapkan oleh SNI seperti yang ditunjukkan pada tabel 1.

Tabel 1. Persyaratan Biodiesel yang ditetapkan oleh SNI [6]

\begin{tabular}{clcc}
\hline No. & \multicolumn{1}{c}{ Parameter } & Satuan & Nilai \\
\hline 1 & Massa jenis pada $40{ }^{\circ} \mathrm{C}$ & $\mathrm{kg} / \mathrm{m}^{3}$ & $840-890$ \\
2 & Viskositas kinematik pd $40{ }^{\circ} \mathrm{C}$ & $\mathrm{mm}^{2} / \mathrm{s}$ & $2,3-6,0$ \\
3 & Angka setana & & min. 51 \\
4 & Titik nyala (mangkok tertutup) & $(\mathrm{cSt})$ & min. 100 \\
5 & Titik kabut & ${ }^{\circ} \mathrm{C}$ & maks. 18 \\
6 & Korosi lempeng tembaga $\left(3\right.$ jam pada $\left.50{ }^{\circ} \mathrm{C}\right)$ & ${ }^{\circ} \mathrm{C}$ & maks. no 3 \\
7 & Residu karbon & & \\
& - dalam contoh asli & $\%$-massa & maks 0,05 \\
& - dalam $10 \%$ ampas distilasi & & (maks. 0,3$)$ \\
8 & Air dan sedimen & $\%$-vol. & maks. 0,05 \\
9 & Temperatur distilasi $90 \%$ & ${ }^{\circ} \mathrm{C}$ & maks. 360 \\
10 & Abu tersulfatkan & $\%$-massa & maks.0,02 \\
11 & Belerang & ppm-m & maks. 100 \\
& & $(\mathrm{mg} / \mathrm{kg})$ & \\
12 & Fosfor & ppm-m & maks. 10 \\
& & $(\mathrm{mg} / \mathrm{kg})$ & \\
13 & Angka asam & mg-KoH/g & maks. 0,8 \\
14 & Gliserol bebas & $\%$-massa & maks. 0,02 \\
15 & Gliserol total & $\%$-massa & maks. 0,24 \\
16 & Kadar ester alkil & $\%$-massa & min. 96,5 \\
17 & Angka iodium & $\%$-massa & maks. 115 \\
18 & Uji Halphen & & Negatif \\
\hline
\end{tabular}

Dalam pembentukan biodiesel metode yang paling banyak digunakan adalah dengan transesterifikasi, dimana bahan baku yang berasal dari berbagai minyak nabati (trygliseride) direaksikan dengan methanol $(\mathrm{CH} 3 \mathrm{OH})$ dengan tambahan katalist seperti natrium hidrosida $(\mathrm{NaOH})$ atau kalium hidrosida $(\mathrm{KOH})$ pada kondisi temperature kurang lebih $65^{\circ} \mathrm{C}$. Selain biodiesel (monoalkil ester) yang terbentuk dari reaksi tersebut juga diperoleh produk sampingan berupa glycerol yang dapat digunakan untuk bahan baku kosmetik dan sabun. Pada proses produksi biodiesel dikenal dua jenis sistem yakni sistem batch dan sistem kontinyu.

Pada pengembangan awal sistem batch cukup popular digunakan, karena instalasi yang sederhana dan teknologinya sudah dikuasai, namun disisi lain sistem ini mempunyai kelemahan karena kapasitas produksi yang rendah. Pengembangan reaktor sistem kontinyu untuk mengatasi rendahnya produktifitas pada sistem batch telah berhasil dikembangkan oleh beberapa peneliti, seperti misalnya Harvey yang mengembangkan oscillatory flow reactor model orifice yang menghasilkan waktu proses hanya 1/8 waktu yang digunakan untuk proses batch. Rheis yang mengembangkan model geometri oscillatory flow mixing model tubular untuk menganalisis pola aliran fluida reaktan selama proses yang menghasilkan model matematik yang cukup berguna. Peneliti lainnya yakni Nouridine mengembangkan sistem kontinyu yang menekankan pada stir tank reactor continue control otmomatik pada pencampuran reaktan dan katalist untuk meningkatkan kapasitas produksi dengan hasil yang lebih baik dibanding sistem batch. Demikian juga Kraai dkk yang menguji efek katalist dan kinerja 
jenis Continuous Contactor Sperator (CCS) mendapatkan peningkatan produksi yang 4 kali lebih besar dibanding sistem batch. Dari studi yang telah dilakukan oleh pengusul yang mengadopsi desain oscillatory flow reactor yang dikembangkan oleh Harvey dkk, diperoleh hasil experimen bahwa sistem kontinyu pada skala pilot-plant dengan menggunakan sirkulasi pompa sentrifugal pada keseluruhan sistem dapat menghasilkan kapasitas produksi enam kali lebih dibanding sistem batch [7]. Rancangan OFR yang sudah diteliti dan dikembangkan terdiri dari suatu tabung dengan panjang tertentu, dimana pada sisi dalam pipa diletakkan orifice pada jarak tertentu untuk memungkinkan reaktan dapat bereaksi secara homogen pada sepanjang alirannya. Jarak antara orifice yang satu dengan lainnya adalah 1,5 kali diameter tabung reaktor sementara, diameter lubang orifice 0.5 diameter tabung, desain ini merefer pada hasil penelitian sebelumnya dan dilakukan modifikasi pada bentuk baffles [7].

Hasil evaluasi dari jenis OFR yang telah diuji ini diperoleh beberapa kesimpulan yakni bahwa sistem pemberian panas pada campuran reaktan dilakukan pada suatu tabung lain dengan menggunakan electrical-heater sehingga pada saat memasuki tabung reaktor yang panjang, secara gradual temperatur reaksi menjadi turun, walaupun pada saat pengujian tabung reaktor sudah diisolasi. Sehingga hal tersebut mempengaruhi kondisi optimum yang diinginkan yaitu mempertahankan temperatur konstant selama reaksi berlangsung. Kesimpulan lain yang diperoleh dari pengujian sebelumnya bahwa jarak antara baffles dan diameter orifice sebagai fungsi dari diameter tabung reaksi yang disarankan oleh peneliti Harvey dkk, menghasilkan pola aliran reaktan tidak optimal untuk menjamin reaksi berlangsung secara homogen, jika diameter tabung reaksi pada unit OFR diperbesar. Dengan pola aliran yang kurang optimal desain tabung reaksi OFR terpaksa dibuat lebih panjang sehingga lama reaktan dalam reactor (resident time) masih cukup lama, sehingga berpengaruh kepada laju produksi [7].

Redesain baffle yang ada didalam tabung reactor untuk mendapatkan pola aliran yang lebih optimal untuk menjamin berlangsungnya reaksi lebih homogen walaupun diameter tabung diperbesar, terutama jika diinginkan memperbesar kapasitas produksi untuk skala industri. Perubahan desain baffle di dalam tabung reaktor dapat dilihat pada Gambar 1 dan 2.

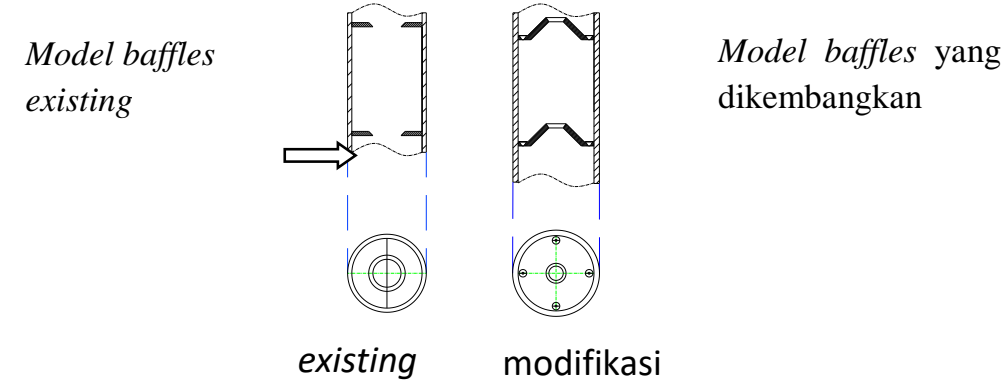

Gambar 1. Perubahan desain Baffles pada Tabung Reaktor Oscillatory Reactor
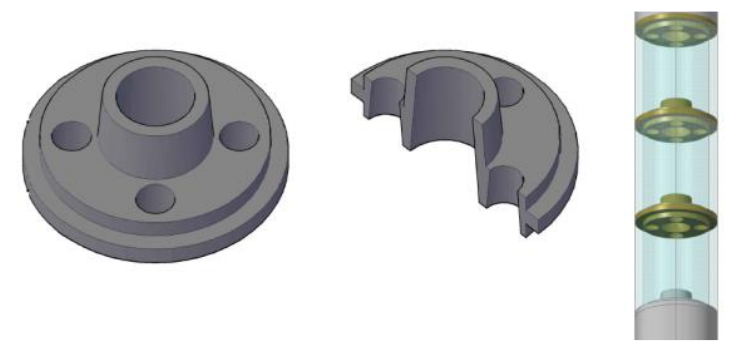

Gambar 2. Bentuk Baffle pada Novel OFR yang dikembangkan 


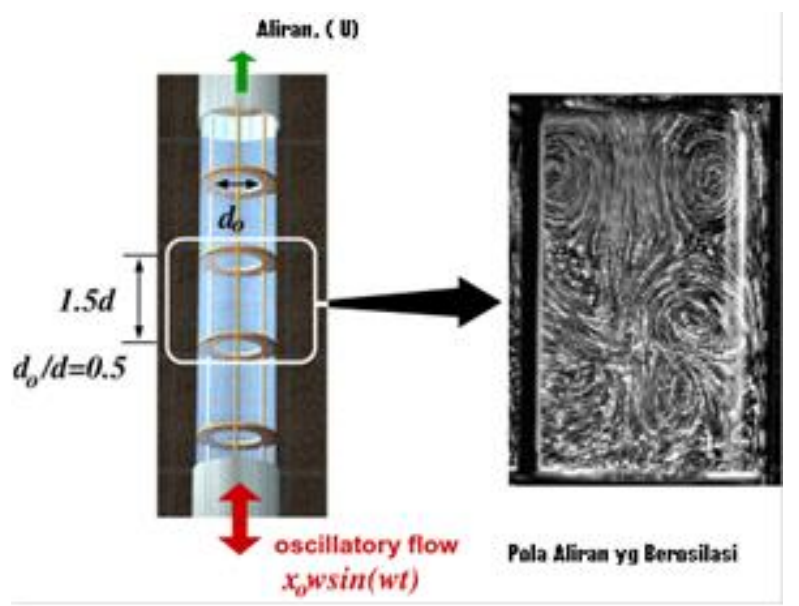

Gambar 3. Posisi Baffles pada Tabung Reaktor Oscillatory Reactor

\section{METODE PENELITIAN}

\section{A. Metode Perancangan}

Kegiatan eksperimental merupakan metode yang akan digunakan pada penelitian ini yang meliputi dari proses desain gambar, pengadaan peralatan, perancangan dan pembuatan komponen ditambah dengan assembly, pengujian untuk kerja sistem dan pengujian mutu produk. Fokus penelitian ini adalah merancang suatu sistem berproduksi biodiesel secara kontinyu dan untuk unit reaktor jenis Oscillatory Flow Reactor (OFR) desainnya sudah diteliti oleh peneliti sebelumnya dan akan mengacu pada desain OFR yang sudah ada.

\section{B. Prosedur Penelitian}

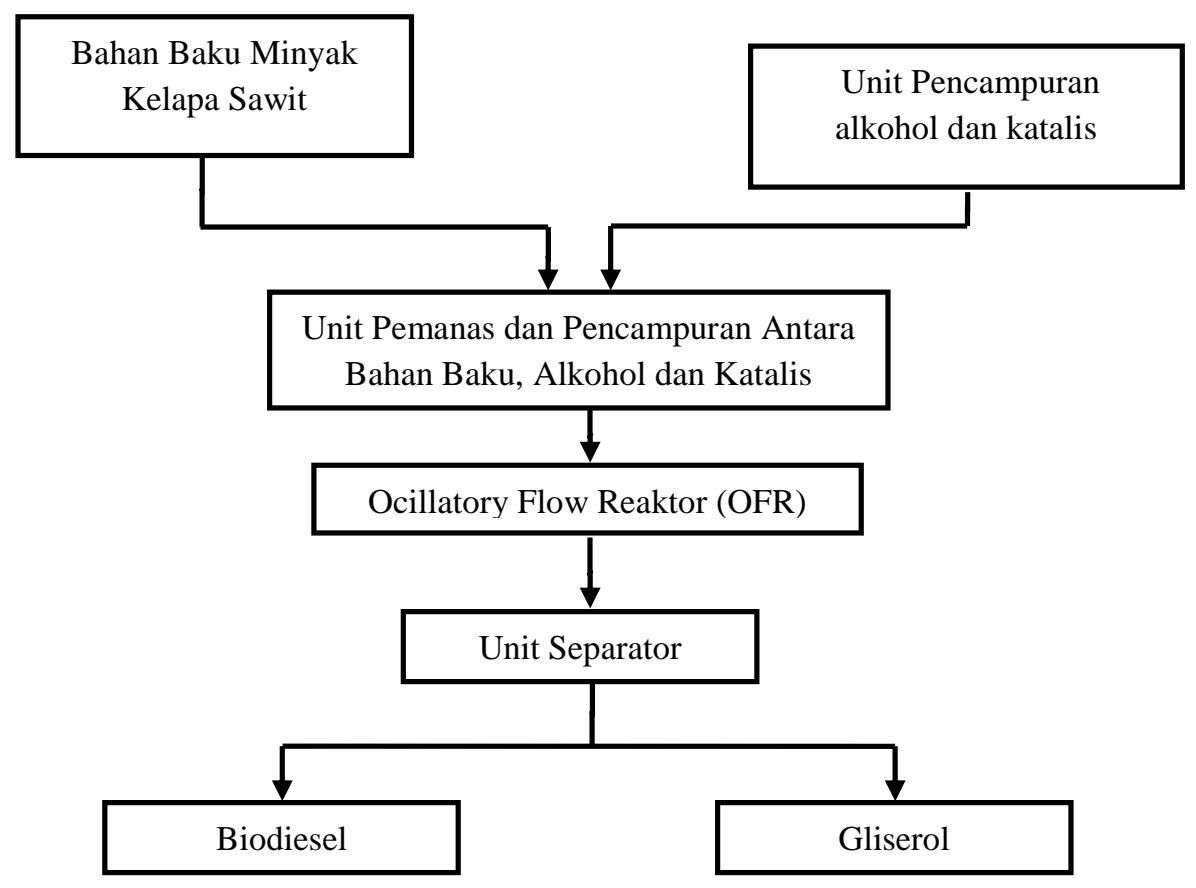

Gambar 4. Blok diagram proses produksi biodiesel 
Metode penelitian yang diterapkan adalah mendesain suatu prototype plant untuk memproduksi biodiesel sistem kontinyu mulai dari proses tahapan pencampuran, tahapan reaksi sampai dengan tahapan separasi yang terintegrasi dalam suatu sistem yang utuh (seperti pada gambar 5). Pada tahapan ini, analisis dilakukan pada sistem yang berhubungan dengan desain OFR yang telah dikembangkan dan kesesuaian desain unit lainnya termasuk evaluasi kapasitas produksi dan mutu. Sebagai indikator keberhasilan yakni membandingkan capaian laju produksi yang berhubungan dengan laju reaksi dengan hasil penelitian sebelumnya baik yang dilakukan oleh peneliti maupun dengan referensi yang dilakukan oleh peneliti lainnya. Adapun desain mesin produksi biodiesel sistem kontinyu dengan menggunakan novel Oscillatory Flow Reactor dapat dilihat pada gambar 6.

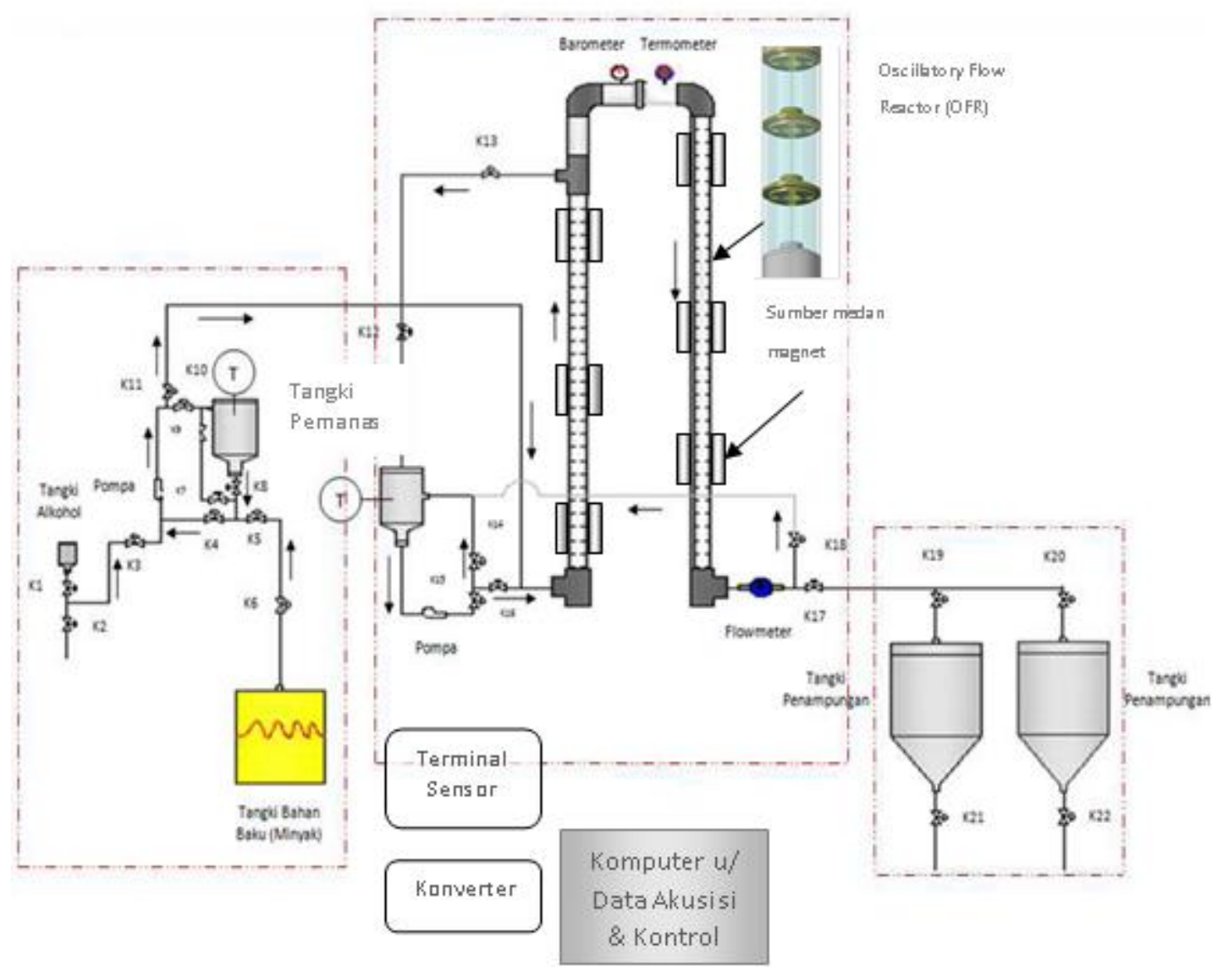

Gambar 5. Skema instalasi proses produksi sistem semi kontinyu dengan menggunakan Oscillatory Flow Reactor (OFR), existing.

Proses penelitian ini dimulai dengan perancangan secara keseluruhan mesin proses produksi biodiesel sistem kontinyu kapasitas 400 liter/jam, mulai dari desain rangka, mendesain instalasi pemipaan, assembly tangki mixer, tangki bahan baku, tangki pencampuran methanol dan katalis hingga tangki hasil, dalam perancangan ini didesain dengan menggunakan software AutoCAD 2010. Untuk desain mikrontroller menggunakan board Arduino Mega 2560 dan software arduino dan desain instalasi listrik menggunakan software Microsoft Visio. 


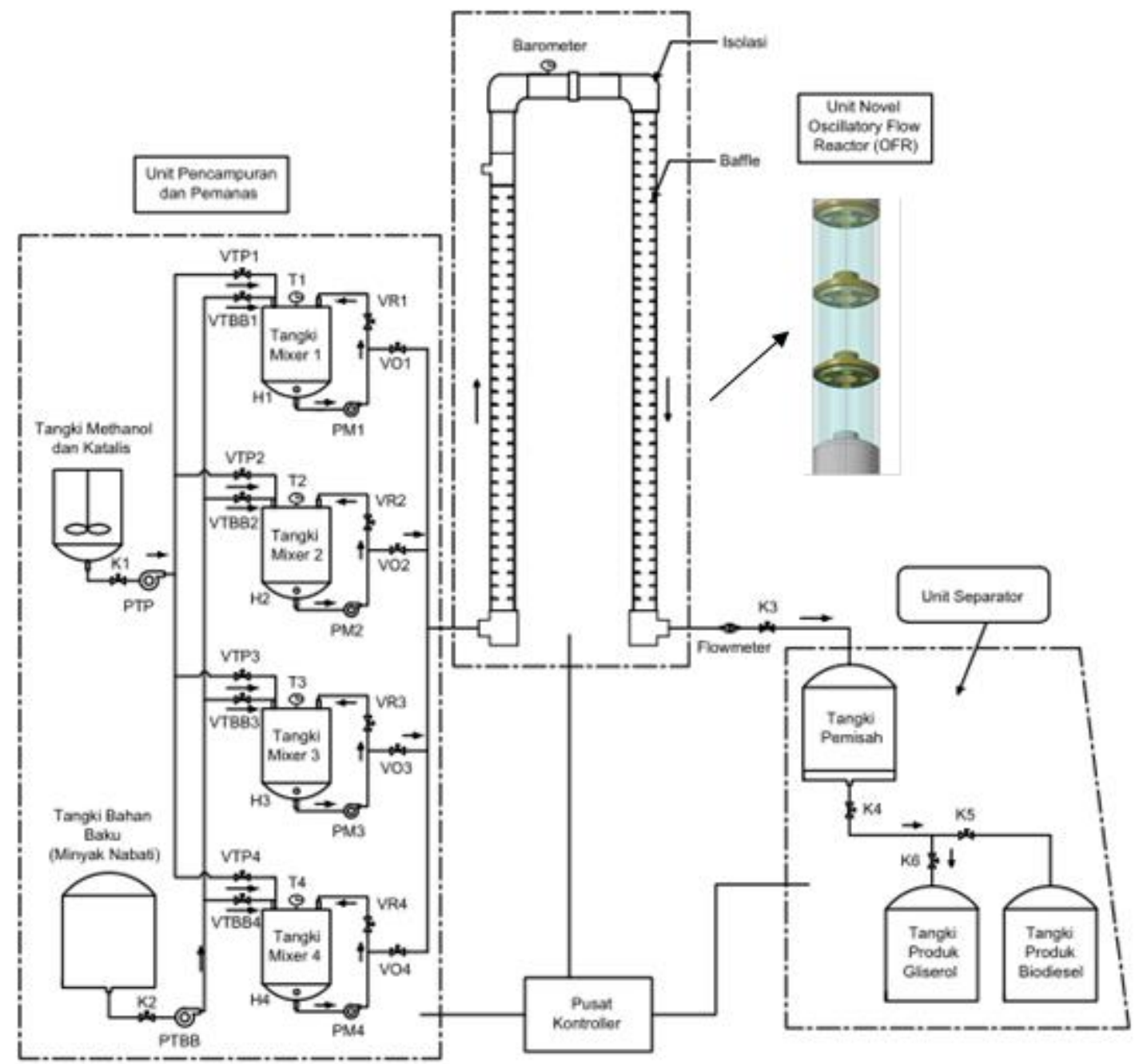

Gambar 6. Desain mesin produksi biodiesel sistem kontinyu kapasitas 400 liter/jam.

Teknik pengukuran yang dilakukan dalam penelitian ini yakni; menguji kinerja sistem kontinyu, mengukur kecepatan aliran, temperatur, kapasitas produksi, dan kualitas produk biodiesel. Untuk mengukur parameter waktu, kecepatan aliran, temperatur dan kapasitas produksi akan digunakan sistem data logger (data akusisi). Adapun untuk mengetahui kualitas produk biodiesel yang meliputi pengukuran parameter seperti density, viskositas, flash point, nilai kalor, kadar air dan titik beku produk menggunakan peralatan laboratorium kimia yang sesuai. Hasil pengukuran lab dibandingkan dengan standard RSNI 20551 atau ASTM-D975.

Untuk tahap pemisahan gliserol dan biodiesel didasarkan pada prinsip efek gravitasi karena adanya perbedaan density antar kedua jenis molekul tersebut. Setelah reaksi kimia dari larutan telah dilakukan pada oscillatory flow reactor secara sempurna maka molekul gliserin (produk sampingan untuk bahan baku kosmetik dan sabun) serta monoalkil ester (biosiesel) sebagai produk utama akan berpisah secara alamiah sehingga gliserin yang dihasilkan mengendap dibagian bawah setelah dibiarkan beberapa selang waktu tertentu dan kemudian akan dikeluarkan secara perlahan - lahan, adapun untuk melihat langsung proses pemisahan antara produk biodiesel dan gliserin menggunakan selang berwarna bening. Pada saat semua gliserinnya sudah dikeluarkan maka katup akan ditutup kembali dan menyisahkan biodiesel. 


\section{Suryanto, Sukma Abadi, Barka Amanah, Wahyudin. Rancang Bangun Mesin Produksi Biodiesel Sistem}

Kontinyu Kapasitas 400 Liter/Jam

Setelah proses perancangan dan pembuatan alat telah dilakukan maka proses selanjutnya yaitu tahap pengumpulan data, namun pelaksanaan pengumpulan data akan termuat dalam pengujian. Data data yang akan menjadi parameter dari efektifitas dari alat yaitu waktu, kecepatan aliran, temperature, dan kapasitas produk biodiesel dan gliserol yang dihasilkan. Data - data tersebut akan diambil pada saat pengujian berlangsung dengan sistem data logger (data akusisi). Adapun untuk mengetahui kualitas produk biodiesel yang meliputi pengukuran parameter seperti density, viskositas, flash point, nilai kalor, kadar air dan titik beku produk menggunakan peralatan laboratorium kimia yang sesuai. Adapun bahan baku yang digunakan dalam proses pengujian untuk menghasilkan biodiesel yaitu sebagai berikut: Minyak kelapa sawit, Methanol, dan Sodium Hidroksida (NaOH).

\section{HASIL DAN PEMBAHASAN}

\section{A. Hasil Pengujian}

Setelah pelaksanaan proses pengujian operasional sistem untuk menghasilkan produk biodiesel, maka telah didapatkan data hasil pengujian dalam hal ini adalah tahap produksi biodiesel dengan sistem kontinyu kapasitas 400 liter/jam secara otomatis berbasis mikrokontroller dan yang menjadi penujukkan parameter yang dapat diketahui saat proses berlangsungnya reaksi mulai dari tahap pencampuran, tahap pemanasan, dan tahap melewati oscillatory flow reactor secara kontinyu hingga ketangki hasil produk biodiesel.

Untuk beberapa pengujian dalam penelitian ini menggunakan komposisi bahan baku yang digunakan sama. Adapun komposisinya dapat dilihat pada tabel 2.

Tabel 2. Komposisi bahan baku setiap tangki mixer

\begin{tabular}{|l|l|l|l|l|l|}
\hline $\begin{array}{l}\text { Minyak } \\
\text { Sawit (liter) }\end{array}$ & $\begin{array}{l}\text { Methanol } \\
(\text { liter })\end{array}$ & $\begin{array}{l}\text { Katalis } \\
(\mathrm{NaOH})(\text { gram })\end{array}$ & $\begin{array}{l}\text { Persentasi Kelapa } \\
\text { Sawit }(\%)\end{array}$ & $\begin{array}{l}\text { Persentasi } \\
\text { mathanol }(\%)\end{array}$ & Keterangan \\
\hline 100 & 17 & 450 & 83 & 17 & $\begin{array}{l}\text { Rasio molaritas minyak } \\
\text { dengan methanol } \\
(1,0: 0,17)\end{array}$ \\
\hline
\end{tabular}

Tabel 3. Data Hasil Pengujian

\begin{tabular}{|c|c|c|c|c|c|c|c|}
\hline \multirow{2}{*}{\multicolumn{2}{|c|}{ Percobaan }} & \multicolumn{3}{|c|}{ Reaksi } & \multicolumn{3}{|c|}{ Hasil } \\
\hline & & \multirow{2}{*}{\begin{tabular}{l}
\multicolumn{1}{c}{ Proses } \\
Pemanasan Minyak \\
Kelapa sawit
\end{tabular}} & \multirow{2}{*}{$\begin{array}{l}\text { Suhu }\left({ }^{\circ} \mathrm{C}\right) \\
32 \text { s/d } 45\end{array}$} & \multirow{2}{*}{$\frac{\text { Waktu (menit) }}{23}$} & $\begin{array}{l}\text { Volume } \\
\text { Biodiesel (liter) }\end{array}$ & $\begin{array}{l}\text { Volume gliserol } \\
\text { ( liter ) }\end{array}$ & Ket \\
\hline \multirow{3}{*}{ A } & 1 & & & & \multirow{3}{*}{105} & \multirow{3}{*}{12} & \\
\hline & 2 & $\begin{array}{l}\text { Pencampuran } \\
\text { Minyak Kelapa } \\
\text { sawit dengan } \\
\text { Methanol }\end{array}$ & $45 \mathrm{~s} / \mathrm{d} 65$ & 30 & & & \\
\hline & 3 & Reaksi pada reaktor & $65 \mathrm{~s} / \mathrm{d} 62$ & 9 & & & \\
\hline & \multicolumn{3}{|r|}{ Total waktu } & 62 menit & & & \\
\hline \multirow{3}{*}{ B } & 1 & $\begin{array}{l}\text { Pemanasan Minyak } \\
\text { Kelapa sawit }\end{array}$ & $32 \mathrm{~s} / \mathrm{d} 45$ & 24 & \multirow{3}{*}{104} & \multirow{3}{*}{13} & \\
\hline & 2 & $\begin{array}{l}\text { Pencampuran } \\
\text { Minyak Kelapa } \\
\text { sawit dengan } \\
\text { Methanol }\end{array}$ & $45 \mathrm{~s} / \mathrm{d} 65$ & 31 & & & \\
\hline & 3 & Reaksi pada reaktor & $65 \mathrm{~s} / \mathrm{d} 62$ & 9 & & & \\
\hline & & & Total waktu & 64 menit & & & \\
\hline
\end{tabular}

\section{B. Analisis data}

1. Persentase produksi biodiesel reaktor sistem kontinyu (\%). 
Berdasarkan hasil pengujian yang diperoleh maka tingkat efektifitas produksi biodiesel yang dihasilkan dapat dihitung seperti pada perhitungan sebagai berikut :

Data - data yang digunakan untuk percobaan A tabel 5 sebagai berikut:

$\mathrm{V}_{\text {bio }} \quad$ : Volume biodiesel yang dihasilkan (liter)

$\mathrm{V}_{\text {tot }} \quad:$ Volume total dari reaktan (liter)

Diketahui $\quad: \mathrm{V}_{\text {bio }}=105$ liter

$$
\begin{aligned}
& \mathrm{V}_{\text {tot }}=117 \text { liter } \\
\text { Perhitungan eff } & =\frac{\text { Vbio }}{\text { Vtot }} \times 100 \% \\
& =\frac{105}{117} \times 100 \% \\
& =89,74 \%
\end{aligned}
$$

2. Persentase gliserol reaktor sistem kontinyu (\%)

Gliserol merupakan hasil produk sampingan dalam pembuatan biodiesel. Berdasarkan sifatnya gliserol yang sangat mudah menggumpal dan juga akan menyebabkan penyumbatan pada aliran bahan bakar di mesin diesel, sehingga harus dipisahkan dari biodiesel. Akan tetapi gliserol dapat dimanfaatkan atau dijadikan sebagai campuran sabun dan berbagai bahan kosmetik.

Berdasarkan hasil pengujian yang didapatkan maka efektifitas dari sisi keluaran gliserol seperti pada perhitungan sebagai berikut :

Data - data yang digunakan percobaan A tabel 5 sebagai berikut :

$$
\begin{array}{ll}
\mathrm{V}_{\text {gli }} & \text { : Volume gliserol yang dihasilkan (liter) } \\
\mathrm{V}_{\text {tot }} & \text { : Volume total dari reaktan (liter) }
\end{array}
$$

Diketahui : $\quad \mathrm{V}_{\mathrm{gli}}=12$ liter

$$
\mathrm{V}_{\text {tot }}=117 \text { liter }
$$

Perhitungan Eff $=\frac{\text { Vgli }}{\text { Vtot }} \times 100 \%$

$$
\begin{aligned}
& =\frac{12}{117} \times 100 \% \\
& =10,25 \%
\end{aligned}
$$

3. Kapasitas produksi reaktor sistem kontinyu (\%)

Data - data yang digunakan untuk percobaan A tabel 4 sebagai berikut :

$\mathrm{V}_{\text {bio }}$ : Volume biodiesel yang dihasilkan ( liter )

$\mathrm{t}$ : Waktu mengalirkan campuran dari reaktor ke tangki

Diketahui :

$\mathrm{V}_{\mathrm{T}}: 117$ liter/jam/tangki

Untuk 4 tangki menghasilkan total produksi : 4 x 117 liter/jam atau 468 liter/jam. Terdiri dari 418 liter biodiesel dan sisanya gliserol sekitar 50 liter. Jadi berdasarkan hasil perhitungan didapatkan jumlah kapasitas produksi yang bisa dihasilkan dari perancangan mesin produksi rata-rata biodiesel sistem kontinyu yaitu sebesar 418 liter. Hasil percobaan untuk kapasitas produksi selengkapnya dapat dilihat pada tabel 4.

Tabel 4. Hasil analisa data pengujian

\begin{tabular}{|l|l|l|l|l|l|}
\hline No & Percobaan & $\begin{array}{l}\text { Persentase } \\
\text { biodiesel } \\
(\%)\end{array}$ & $\begin{array}{l}\text { Persentase } \\
\text { Gliserol } \\
(\%)\end{array}$ & $\begin{array}{l}\text { Kapasitas produksi } \\
\text { total } \\
(\text { Q }) \\
(\text { liter/jam })\end{array}$ & $\begin{array}{l}\text { Kapasitas produksi } \\
\text { biodiesel } \\
\left(\begin{array}{l}\text { Q }) \\
(\text { liter } / \text { jam })\end{array}\right.\end{array}$ \\
\hline 1 & I & 89,74 & 10,25 & 117 & 105 \\
\hline 2 & II & 88,88 & 11,11 & 117 & 104 \\
\hline
\end{tabular}


221 Suryanto, Sukma Abadi, Barka Amanah, Wahyudin. Rancang Bangun Mesin Produksi Biodiesel Sistem Kontinyu Kapasitas 400 Liter/Jam

4. Kecepatan aliran dalam reaktor ( Vs )

Dari hasil pengukuran flow sensor diperoleh data seperti pada lampiran F diperoleh data sebagai berikut, debit rata-rata:

$$
\begin{aligned}
& \mathrm{Q}_{\text {rata-rata }}=10 \text { liter } / \text { menit }=0,000167\left(\mathrm{~m}^{3} / \text { detik }\right) \\
& \mathrm{D} \quad=\text { Diameter dalam penampang reaktor }(\mathrm{m}) \\
& \text { Diketahui } \quad \mathrm{Q}=0,000167 \mathrm{~m}^{3} / \text { detik } \\
& \mathrm{A}=\frac{1}{4} \pi \mathrm{D}^{2} \\
& \text { Perhitungan } \mathrm{Vs}=\frac{\mathrm{Q}}{\mathrm{A}}=0,000506451 \mathrm{~m}^{2} \\
& =\frac{0,000167 \mathrm{~m}^{3} / \mathrm{s}}{0,000506451 \mathrm{~m}^{2}} \\
& =0,33 \mathrm{~m} / \mathrm{s}
\end{aligned}
$$

5.

Bilangan Reynold

$\mathrm{V}_{\mathrm{S}} \quad=$ Kecepatan aliran $(\mathrm{mm} / \mathrm{s})$

$\mathrm{D} \quad=$ diameter pipa $(\mathrm{mm})$

$\mathrm{V} \quad=$ viskositas kinematik $\left(\mathrm{mm}^{2} / \mathrm{s}\right)$

$\operatorname{Re} \quad=\frac{V s \times D}{v}$

$$
\begin{aligned}
& =\frac{0,33 \times 10^{3} \mathrm{~mm} / \mathrm{s} \mathrm{x} 25,4 \mathrm{~mm}}{4,5 \mathrm{~mm}^{2} / \mathrm{s}} \\
& =1862,67
\end{aligned}
$$

Tabel 5. Hasil perhitungan Bilangan Reynold

\begin{tabular}{|l|l|l|l|l|}
\hline No. & $\begin{array}{l}\text { Kecepatan Aliran } \\
(\mathrm{mm} / \mathrm{s})\end{array}$ & $\begin{array}{l}\text { Diameter Pipa } \\
(\mathrm{mm})\end{array}$ & $\begin{array}{l}\text { Viskositas Kinematik } \\
\left(\mathrm{mm}^{2} / \mathrm{s}\right)\end{array}$ & Bilangan Reynold \\
\hline 1 & 330 & 25,4 & 4,5 & 1862,95 \\
\hline 2 & 390 & 25,4 & 4,5 & 2201,33 \\
\hline
\end{tabular}

Berdasarkan hasil perhitungan didapatkan bilangan reynold dari perancangan mesin produksi biodiesel sistem kontinyu antara 1862,95- 4307,84. Nilai Bilangan Reynold menunjukkan aliran dalam reaktor pada percobaan I dan II dalam kondisi laminar.

6. Kualitas Produk Biodiesel

Berdasarkan hasil 2 sampel produk biodiesel yang telah dilakukan uji mutu dari beberapa parameter penting dari biodiesel (density, kinematic viscosity, flash point, glycerol content, nilai kalor, pour point). Hasil dari uji mutu tersebut menunjukkan parameter kualitas biodiesel masuk dalam kategori baik, hal demikian karena semua parameter masuk dalam standar pengukuran ASTM D6751 dan RSNI EB 20551. Hasil uji mutu biodiesel yang dilakukan di Laboratorium Kimia dan Laboratorium Energi Politeknik Negeri Ujung pandang dapat dilihat pada Tabel 6.

Tabel 6. Parameter kualitas biodiesel berdasarkan standar (American and Indonesian ).

\begin{tabular}{|l|l|l|l|l|}
\hline No. & Standar spesifikasi properties & $\begin{array}{l}\text { RSNI } \\
\text { EB20551 }\end{array}$ & $\begin{array}{l}\text { ASTM } \\
\text { D6751 }\end{array}$ & $\begin{array}{l}\text { Hasil Pengujian } \\
\text { Biodiesel }\end{array}$ \\
\hline 1 & Density $\left(\mathrm{kg} / \mathrm{m}^{3}\right)$ & $850-890$ & $860-900$ & 865 \\
\hline
\end{tabular}




\begin{tabular}{|l|l|l|l|l|}
\hline 2 & $\begin{array}{l}\text { Kinematic Viscosity, } 41^{\circ} \mathrm{C}, \\
(\mathrm{mm} / \mathrm{sec})\end{array}$ & $2.3-6.0$ & $1.9-6.0$ & $2.0-6.0$ \\
\hline 3 & Flash point, $\left({ }^{0} \mathrm{C}\right)$ & Min 100 & $>=130$ & $125-139$ \\
\hline 4 & Glycerol content, $(\%$ mass $)$ & $<=0.24$ & $<=0.24$ & 0.32 \\
\hline 5 & Nilai Kalor $(\mathrm{MJ} / \mathrm{Kg})$ & N/A & N/A & 41.05 \\
\hline 6 & Pour point, ${ }^{0} \mathrm{C}$ & 18 & 0 & 9 \\
\hline
\end{tabular}

Selanjutnya data yang telah diperoleh, dibandingkan dengan perolehan data dari penelitian sebelumnya. Penyajian data ini bertujuan menilai apakah modifikasi yang dilakukan berhasil membuat kinerja dari sistem menjadi lebih optimal dari penelitian sebelumnya. Adapun data perbandingan dari penelitian sebelumnya dapat dilihat pada tabel 7.

Tabel 7. Perbandingan Hasil data sebelum dan setelah perancangan mesin produksi biodiesel

\begin{tabular}{|c|c|c|c|c|c|}
\hline \multirow{2}{*}{ No. } & \multirow{2}{*}{ Parameter } & \multirow{2}{*}{ DATA } & \multicolumn{2}{|l|}{ Percobaan } & \multirow[t]{2}{*}{ Rata-Rata } \\
\hline & & & $\mathrm{I}$ & II & \\
\hline \multirow{2}{*}{1} & \multirow{2}{*}{$\begin{array}{l}\text { Waktu reaksi di } \\
\text { reaktor } \\
\text { (menit) }\end{array}$} & $\begin{array}{l}\text { sebelum } \\
\text { Modifikasi }\end{array}$ & 8:00 & 9:00 & $8: 30$ \\
\hline & & $\begin{array}{l}\text { setelah } \\
\text { Modifikasi }\end{array}$ & 3:00 & $2: 50$ & $2: 55$ \\
\hline \multirow{2}{*}{2} & \multirow{2}{*}{$\begin{array}{l}\text { Persentase } \\
\text { Biodiesel } \\
(\%)\end{array}$} & $\begin{array}{l}\text { sebelum } \\
\text { Modifikasi }\end{array}$ & 87,93 & 87,06 & 87,49 \\
\hline & & $\begin{array}{l}\text { setelah } \\
\text { Modifikasi }\end{array}$ & 89,74 & 88,88 & 89,31 \\
\hline \multirow{2}{*}{3} & \multirow{2}{*}{$\begin{array}{l}\text { Persentase gliserol } \\
(\%)\end{array}$} & $\begin{array}{l}\text { sebelum } \\
\text { Modifikasi }\end{array}$ & 12,07 & 12,94 & 12,50 \\
\hline & & $\begin{array}{l}\text { setelah } \\
\text { Modifikasi }\end{array}$ & 10,25 & 11,11 & 10,68 \\
\hline \multirow{2}{*}{4} & \multirow{2}{*}{$\begin{array}{l}\text { Kecepatan aliran } \\
(\mathrm{mm} / \mathrm{dtk})\end{array}$} & $\begin{array}{l}\text { sebelum } \\
\text { Modifikasi }\end{array}$ & 223,70 & 306,05 & 264,87 \\
\hline & & $\begin{array}{l}\text { setelah } \\
\text { Modifikasi }\end{array}$ & 330 & 390 & 360 \\
\hline \multirow{2}{*}{5} & \multirow{2}{*}{ Reynold } & $\begin{array}{l}\text { sebelum } \\
\text { Modifikasi }\end{array}$ & 1431,5862 & 1717,9034 & 1574,7448 \\
\hline & & $\begin{array}{l}\text { setelah } \\
\text { Modifikasi }\end{array}$ & 1862,95 & 2201,33 & 2032,14 \\
\hline
\end{tabular}

Hasil yang diperoleh dari data pengujian dengan menggunakan sistem produksi yang diredesain dan menggabungkan dengan Oscillatory Flow Reactor (OFR) dan sistem control otomatik, menunjukkan bahwa kapasitas produk prototype dapat mencapai rata-rata diatas 400 liter/jam diluar produk sampingnya yakni gliserol yang berkisar 68 liter perjam (total produk biodiesel+gliserol ratarata 468 liter/jam). Demikian juga sistem kontrol otomatik yang didesain untuk menjamin proses berlangsung secara kontinyu juga bekerja dengan baik. Empat tangki mixer dan heater yang mempunyai kapasitas masing-masing kurang lebih 120 liter dapat dikontrol secara sekuen dan bersiklus untuk beroperasi terus menerus mensuplai reaktan ke OFR yang bekerja dengan sistim kontinyu.

Desain kapasitas heater yang besarnya 2000 Watt per tangki mixer sudah memenuhi syarat untuk menuntaskan pencapaian $65^{\circ} \mathrm{C}$ panas yang dinginkan dari pemanasan reaktan yang berlangsung selama kurang lebih 55 menit. Demikian juga desain secara keseluruhan dari sistem katup solenoid yang mengatur aliran reaktan dari setiap tahapan dalam keseluruhan sistem instalasi produksi bekerja secara baik sesuai dengan desain. Adapun desain pompa suplai bahan baku, pompa methanol dan pompa sirkulasi dapat mensuplai debit fluida sesuai dengan desain yang diinginkan yakni sekitar 15 sampai dengan 18 liter permenit. 
Kendala yang masih muncul pada kontroller adalah bahwa sistim control belum mampu memantau dan membatasi hal-hal yang terjadi diluar setting atau jika terjadi emergency kondisi yang tidak diharapkan dalam proses. Proses masih ditanggulangi dengan pengaturan sistem secara manual. Molaritas campuran methanol dan katalist masih dilakukan secara manual dan belum dikontrol secara otomatik. Diperlukan peralatan dan sensor yang cukup rumit untuk hal ini sehingga hal ini belum dilakukan. Namun karena komposisi campuran methanol dan katalist yang tidak terlalu besar dalam proses produksi sehingga pencampuran sistem manual tidak menggangu sistem kontinyu yang berlangsung keseluruhan proses.

Hasil pengujian laboratorium juga yang dilakukan diperoleh kualitas produk biodiesel hampir semuanya masuk dalam range yang dipersyaratkan sesuai standard ASTM/Amerika maupun merujuk pada mutu Biodiesel Indonesia/RSNI. Ini dapat dilihat pada Tabel 8, dimana properties produk biodiesel yang dihasilkan seperti density, viskositas, flash point, dan total sulphur semuanya sudah dalam batas yang diijinkan. Ada beberapa sifat hasil mutu biodiesel yang belum diukur secara seksama karena keterbatasan alat ukur namun jika dilihat secara fisis, maka produk yang dihasilkan terlihat warnanya kuning tua bening dengan aroma yang spesifik yang mengindikasikan mutu yang baik.

\section{KESIMPULAN}

Berdasarkan hasil perancangan dan pengujian mesin produksi biodiesel sistem kontinyu dengan kapasitas 400 liter/jam dapat disimpulkan bahwa :

a. Komponen-komponen yang telah dirancang bangun yaitu sebagai berikut:

- Assembly tangki mixer, tangki pencampuran, tangki bahan baku dan tangki hasil.

- Instalasi pemipaan dan instalasi kelistrikan sebagai komponen pendukung dari mesin produksi biodiesel sistem kontinyu.

- Penambahan alat pengukur sensor temperature dan sensor level untuk pendataan temperature dan volume didalam tangki secara real time.

b. Modifikasi yang dilakukan berhasil membuat kinerja dari sistem semi kontinyu menjadi lebih optimal dari penelitian sebelumnya.

\section{DAFTAR PUSTAKA}

[1] S. Dyah P, "Produksi Biodiesel dari Mikroalga Chlorella sp dengan Metode Esterifikasi In-Situ." Universitas Diponegoro, 2011.

[2] S. Özgül and S. Türkay, "In situ esterification of rice bran oil with methanol and ethanol," J. Am. Oil Chem. Soc., vol. 70, no. 2, pp. 145-147, 1993.

[3] J. Van Gerpen, "Business Management for Biodiesel Producers: August 2002--January 2004," National Renewable Energy Lab., Golden, CO (US), 2004.

[4] S. Zuhdi, Cilacap (1830-1942): bangkit dan runtuhnya suatu pelabuhan di Jawa. Kepustakaan Populer Gramedia, 2002.

[5] G. Knothe, "Dependence of biodiesel fuel properties on the structure of fatty acid alkyl esters," Fuel Process. Technol., vol. 86, no. 10, pp. 1059-1070, 2005.

[6] T. H. Soerawidjaja, "Raw Material Aspects of Biodisel Production in Indonesia," in Seminar "Business Opportunities of Biodisel into the Fuel Market in Indonesia, 2006, vol. 8.

[7] S. Suryanto, A. Apollo, A. Zulkifli, and R. Ridwansa, "MODIFIKASI OSCILLATORY FLOW REACTOR (OFR) UNTUK MENINGKATKAN PRODUKSI BIODIESEL SISTEM KONTINYU," J. Tek. Mesin SINERGI, vol. 16, no. 1, pp. 97-106, 2018. 